\title{
Zarządzanie emocjami w Sejmie. Rola marszałków
}

\author{
Michał Lesiak \\ Uniwersytet Łódzki
}

\begin{abstract}
Abstrakt. Artykuł koncentruje się na analizie działań podejmowanych przez marszałka/marszałków Sejmu w celu opanowania emocji, które pojawiają się na sali sejmowej w trakcie obrad. Autor skupił się na interakcyjnych technikach (zarówno formalnych, jak i nieformalnych) wykorzystywanych przez marszałków w celu skutecznego przeprowadzenia obrad sejmowych. Celem artykułu jest analiza środków, jakie może zastosować marszałek, aby emocje nie zakłóciły procesu decyzyjnego ciała ustawodawczego.

Słowa kluczowe: socjologia emocji, polityka, zarządzanie emocjami, wstyd, symboliczny interakcjonizm, Erving Goffman, Thomas Scheff, Arlie Russel Hochschild
\end{abstract}

W teatrze iluzja tworzona przez aktora zostaje rozpoznana z wyprzedzeniem przez niego samego oraz widownię. W codziennym życiu częściej zdarza się nam jej poddawać.

A. R. Hochschild

\section{Wstęp}

Obecność emocji w polityce nie powinna nikogo zaskakiwać. „Choć stopień, w jakim emocje przenikają współczesny dyskurs polityczny, jest wyjątkowy ze względu na przemiany, jakie przeszła komunikacja pod wpływem telewizji i nowych 
mediów, to jednak sama obecność emocji w komunikacji politycznej nie jest niczym nowym. Już w czasach starożytnych emocje były chętnie wykorzystywanym narzędziem polityki" (Miłkowska-Samul 2013: 173). Politycy wykorzystują emocje do budowania własnego wizerunku oraz do niszczenia cudzej reputacji. „Emocje w tak postrzeganym dyskursie politycznym mają charakter instrumentalny, dodając siły oddziaływania wypowiedziom i przekazując ładunek wartościujący" (Miłkowska-Samul 2013: 174).

Pracownik w trakcie każdego dnia pracy narażony jest na stres, który wymaga opanowania przez niego sztuki radzenia sobie z emocjami, zarządzania nimi. Wnioski z badań Arlie Russell Hochschild (2009) opisane w książce Zarządzanie emocjami pozwalają na zrozumienie, w jaki sposób ludzie pracujący w zawodach, w których konieczna jest „praca z emocjami”, radzą sobie z nimi. Autorka konstruuje swoje wnioski dotyczące zarządzania emocjami odwołując się do prac innych badaczy oraz badań własnych nad stewardesami. Analiza Hochschild skupia się także na wybranych aspektach prywatnego, codziennego życia ludzi. Praca, w którą zaangażowane są emocje, wymaga ciągłej samokontroli. „W tego typu pracy produktem jest stan umysłu” (Hochschild 2009: 6). Polityka również jest zawodem, w którym emocje odgrywają ogromną rolę, chociażby ze względu na ich medialność - kontrola nad wrażeniami wzbudzanymi u odbiorców/wyborców. „Właśnie możliwość docierania przekazu do nieograniczonej liczby odbiorców sprawia, że media masowe stały się współcześnie głównym środkiem publikowania komunikatów politycznych. [...] w działalności politycznej oprócz legitymizacji wyborczej (uzasadniania wynikami wyborów) ważna stała się legitymizacja medialna, oparta na atrakcyjności wizerunku medialnego..." (Fras 2005: 46). Dlatego uważamy za uzasadnioną analizę zawodu polityka w kontekście pracy nad emocjami, prezentowanymi w mediach masowych. 
Hochschild pisze, że w nauce można spotkać się z trzema dyskursami dotyczącymi emocji i pracy z/nad uczuciami. Pierwszy z nich mówi, że praca wymaga coraz niższych kwalifikacji, a rola pracownika ulega zdeprecjonowaniu, autorka jednak podaje w wątpliwość to twierdzenie, mówiąc, że w tym przypadku badacze pomijają zawody interpersonalne. Drugi dyskurs natomiast skupia się na jednostce, a nie na ogólnej organizacji pracy, zajmując się ekspresją uczuć. Wadą tego podejścia według Hochschild jest brak możliwości umiejscowienia owej pracy nad ekspresją w szerszym kontekście. Na jego podstawie trudno wyjaśnić pojawiające się wątpliwości, np. dlaczego linie lotnicze szkolą swoich pracowników, aby się uśmiechali lub jaki zysk wiąże się z pracą emocjonalną. „Ostatni z dyskursów dotyczących emocji stawia pytanie o to, czym są emocje i jak możemy sobie z nimi radzić” (Hochschild 2009: 11).

W życiu społecznym uczucia mogą stać się walutą, która będzie podlegała regułom wymiany. Jeśli ktoś jest dla nas życzliwy, powinniśmy odpłacić mu tym samym. Jednak podczas pracy, która jest związana z zarządzaniem emocjami, wymiana między pracownikiem a klientem nie musi być równa. Kelner lub stewardesa muszą uśmiechać się do klienta, klient natomiast nie musi odwzajemniać tych uczuć (w przypadku stewardesy i kelnerki pracodawca może narzucać określony styl zachowania). Taka sytuacja doprowadza do powstania możliwości/konieczności zarządzania uczuciami. Stewardesa może czuć niechęć czy wręcz nienawiść do klienta, ale musi się do niego uśmiechać i spełniać jego wymagania. Hochschild taką rozbieżność między prywatnym aktem zarządzania emocjami i aktem publicznym proponuje nazywać transmutacją. Takie zarządzanie emocjami jest fundamentem dla cywilizowanego życia. Podobnie jak Freud zwraca uwagę na to, że kultura hamuje i poskramia instynkt seksualny, tak Hochschild zauważa, że negatywne, wewnętrzne emocje mogą być hamowane przez wymogi cywilizacyjne, „proces cywilizacji polega na zmianie, na ewolucji 
zachowań i odczuć ludzi, postępującej w określonym kierunku” (Elias 1980: 367). „Teraz znaczna część napięć, które dawniej wyładowywały się w bezpośrednim starciu człowieka z człowiekiem, musi ulec jako napięcie wewnętrzne rozładowywaniu w walce człowieka z samym sobą" (Elias 1980: 459).

Politycy w przypadku „starć” na mównicy obdarzają się wzajemnie podobnymi - negatywnymi - emocjami. Osoby biorące udział w konfrontacji starają się pokazać swojego oponenta w podobny - negatywny sposób. „Emocje pełnią funkcję sygnalizacyjną. Nie wszystkie sygnalizują zagrożenie, ale wszystkie sygnalizują «mnie», przez którego patrzę na «ciebie». Sygnalizują często podświadomy punkt widzenia, jaki przyjmujemy patrząc na świat" (Hochschild 2009: 32).

W przypadku wystąpień sejmowych, politycy nie muszą powściągać swoich emocji (negatywnych czy pozytywnych), kierowanie negatywnych przekazów w stronę partii opozycyjnej zwiększa emocjonalność wystąpień i powoduje, że dane wystąpienie staje się atrakcyjne medialnie, co przekłada się na pozyskanie wyborczych głosów. „Politycy mają tendencję do ukrywania osobistych emocji, jednak wykorzystują powszechnie afektywne konotacje, ich działanie jest $\mathrm{w}$ większości zaplanowane i ujęte w normatywne ramy strategii politycznej" (Krawczyk-Antońska 2013: 63). „Ekspresja oburzenia zawiera w sobie milcząco narzucone założenie, iż dany czyn, a więc i osoba, zasługują na potępienie. [...] Wszystko to służy wyręczeniu audytorium w wysiłku samodzielnej oceny sytuacji..." (Miłkowska-Samul 2013: 175).

Uczucia mogą być wykorzystywane w życiu prywatnym, jak i zawodowym jako wskazówki do podjęcia określonego działania. W tym miejscu powstają jednak dwa zagrożenia. Pierwsze związane jest z uczuciem (wskazówką) i jego interpretacją. Drugie wiąże się z relacją między bodźcem a reakcją.

Autorka, w kontekście zarządzania emocjami, posługuje się dwoma Goffmanowskimi pojęciami: działanie powierzchowne 
i działanie głębokie. Działanie powierzchowne to takie, w którym uczucia wyrażane są poprzez gesty i mimikę twarzy. Działanie głębokie natomiast to takie, w którym staramy się odczuć wewnętrznie dane uczucie. Można wyróżnić dwie metody działania głębokiego: bezpośrednie - przez wzbudzenie uczucia i pośrednie - przez wykorzystanie wyćwiczonej wyobraźni (Hochschild 2009: 42). W przypadku sprzedaży działania powierzchowne i działania głębokie sprawiają, że twarz oraz uczucia stają się zasobem. Podobnie jak towar, który podlega wymianie. Zapanowanie nad własnymi emocjami powoduje, że jednostka wpływa na emocje partnera interakcji. Stewardessa, która uśmiecha się do rozzłoszczonego klienta linii lotniczych, sprawia, że zdenerwowany pasażer może dokonać reinterpretacji sytuacji (jako mniej konfliktowej) i uspokoić się. „Emocjonalizacja komunikatu jest zatem zbyt efektywną techniką perswazyjną, by politycy z niej rezygnowali, w związku z czym znaczna część przekazów politycznych wykorzystuje emocje w celu zjednania sobie słuchaczy, przekonania ich do swojej osoby i swojego programu, ale także do pogrążenia rywali w oczach wyborców" (Miłkowska-Samul 2013: 180).

Emocje, które towarzyszą politykowi podczas wystąpienia, sprawiają, że w słuchaczach zostaną wzbudzone podobne odczucia związane z omawianym tematem. Zarządzanie własnymi emocjami nakłada ramy interpretacyjne na omawiany problem.

\section{Emocje a interakcjonizm}

Próbę rozwinięcia teorii emocji opartą na interakcjonizmie symbolicznym podjęła Susan Shott. Autorka stwierdziła, że perspektywa, jaką jest „[...] symboliczny interakcjonizm, jest szczególnie odpowiednia do wyjaśniania konstrukcji emocji przez aktora...” (Shott 1979: 1318). W swoich rozważaniach nawiązywała ona do 
chicagowskiej szkoły, podkreślając, że „emocje związane są zarówno z procesami podniecenia fizjologicznego, jak i etykietowaniem tego podniecenia jako afektu lub emocji” (Turner 2008: 497). Shott uważa, że zajmując się badaniem emocji, koniecznie należy odwołać się do perspektywy socjologicznej. „Co ważniejsze, wyjaśnienie znaczenia emocjonalnej ekspresji wymaga socjologicznej perspektywy; [...] teorie fizjologiczne lub psychologiczne są niewystarczające" (Shott 1979: 1318).

Według Shott przyjmowanie roli jest związane z dwoma typami uczuć: emocje występujące podczas refleksyjnego przyjmowania roli (reflexive role-taking emotions), które obejmują poczucie winy, wstyd, zażenowanie, dumę i próżność; emocje występujące podczas empatycznego przyjmowania roli (empathic role-taking emotions), które wywołane są poprzez psychiczne postawienie się w czyjejś pozycji (Shott 1979: 1324). Dla autorki najważniejszymi emocjami w procesie komunikowania są: poczucie winy, wstyd, zażenowanie, duma, próżność oraz empatia. Zachowanie jednostki przyjmującej określoną rolę w interakcjach jest w znaczącym stopniu determinowane przez wymienione uczucia (Turner 2008: 498). Poczucie winy, wstyd i zażenowanie pojawiają się podczas zachowań dewiacyjnych i każą je. Każde jest jednak wywoływane w innych okolicznościach (Shott 1979: 1325).

1) Poczucie winy - pojawia się, kiedy jednostka uświadamia sobie, że jej zachowanie (faktyczne lub zakładane) odbiega od tego, jak powinna się zachować w danej sytuacji, doprowadza to do unikania osób, które powodują powstawanie tego uczucia.

2) Wstyd - nie jest tym samym co zażenowanie, jednak zażenowanie dość często traktowane jest jako forma wstydu (Shott 1979: 1325). Wstyd powstaje, gdy jednostka jest przekonana o własnej moralnej niedoskonałości (lub uważa, że inni tak uważają). 
3) Zażenowanie - powstaje gdy zarówno jednostka, jak i inni postrzegają prezentowaną tożsamość sytuacyjną jednostki jako niestosowną. Wynika ze świadomości, że inni odbiorą czyjeś przedstawienie jako nieudolne (Shott 1979: 1325).

4) Duma - duma i próżność związane są ze zwiększeniem własnej samooceny, która wiąże się z przyjęciem roli uogólnionych innych (rzeczywistych lub wyimaginowanych) i doszukaniem się z ich strony aprobaty (Shott 1979: 1326). Związana jest z rodzajem samoakceptacji, który związany jest z przyjmowaniem roli innych i uogólnionych innych.

5) Próżność - w przeciwieństwie do dumy jest nietrwałym i przemijającym uczuciem, które wskazuje na niepewność jednostki co do aprobaty ze strony innych (Shott 1979: 1326).

6) Empatia - uczucie złożone, które działa na dwóch poziomach: jednostka odczuwa te same emocje, które odczuwają inni; jednostka generuje zrozumienie tego, co mogłaby odczuwać, gdyby znajdowała się na miejscu innego.

\section{Emocje w koncepcji Thomasa Scheffa i Suzanne Retzinger}

Według Sheffa i Retzinger wstyd i duma są budulcem stosunków interpersonalnych. Definiują oni wstyd jako klasę dużej rodziny emocji, która obejmuje nie tylko wstyd i upokorzenie, ale także „dyskretny” wstyd - skromność, nieśmiałość itp. (Scheff, Retzinger 2000). Według tych autorów wstyd jest najważniejszą emocją, ponieważ pełni wiele społecznych i psychologicznych funkcji, więcej niż inne emocje (Scheff, Retzinger 2000), mianowicie:

a) jest kluczowym elementem sumienia, poczucia moralności, ponieważ sygnalizuje moralny występek, nawet bez myśli i słów; 
b) powstaje w elementarnych sytuacjach, w których istnieje prawdziwa lub wyimaginowana groźba. Sygnalizuje kłopoty w relacjach. Jeśli ktoś uważa, że jego zachowanie było nieodpowiednie lub dewiacyjne, powstaje nie tylko wewnętrzna luka stworzona między zachowaniem a ideałami, ale także przepaść między ideałami grupy i samego siebie;

c) odgrywa kluczową rolę w regulacji ekspresji, a nawet świadomości występowania wszystkich innych emocji, np. złość, strach, smutek i miłość nie mogą być wyrażone bez zawstydzenia.

W społeczeństwach zachodnich wstyd jest prawie całkowicie tłumiony i ukrywany. Można by się wstydzić, że ktoś był w stanie smutku, strachu, gniewu, a nawet zażenowania. O istotności wstydu w życiu społecznym świadczy także fakt, że jest on najbardziej utajaną ze wszystkich emocji.

Wstyd w literaturze jest również łączony z lękiem, „uczucie wstydu to specyficzne wzruszenie, rodzaj lęku, który reprodukuje się w jednostce automatycznie i nawykowo z pewnych określonych powodów" (Elias 1980: 450).

W koncepcji Scheffa i Retzinger (Scheff, Retzinger 2000: 12) istotne jest pojęcie pułapki uczuć (feeling traps). Jednostka wpada w nią, kiedy zaczyna się wstydzić tego, że się wstydzi, np. świadomość reakcji fizjologicznych (zaczerwieniona twarz) powoduje, że jednostka zaczyna czuć zażenowanie z powodu swojego zawstydzenia - wpada w pułapkę. Mniej oczywistym przykładem pułapki uczuciowej jest złość z powodu własnego zawstydzenia, lub zawstydzenie z powodu złości. Pętla ta przyjmuje formę bezsilnej złości lub upokorzenia. Uczucia te mogą doprowadzić do powstania spirali gniewu/wstydu (Scheff, Retzinger 2000: 12; Konecki 2014).

„Emocje prowadzą więc ludzi do odgrywania ról w taki sposób, który jest spójny z oczekiwaniami normatywnymi, definicjami sytuacji, wartościami kulturowymi i wysoko cenionymi odczuciami na temat siebie" (Turner 2008: 504). 
Wydaje się, że obecnie granica tego, co rozumiane jest jako wstyd, przesuwa się, „brak jednoznacznie stanowionych (i egzekwowanych) norm społecznych ogranicza także odczuwanie wstydu jako emocji wynikłej z poczucia złamania reguły przy jednoczesnym doznawanym lub wyimaginowanym potępieniu ze strony otoczenia" (Górska 2009: 257).

Politycy zazwyczaj budują wizerunek swój oraz partii. Podobnie jak stewardesy muszą dbać o wizerunek linii lotniczych, tak politycy muszą dbać o wizerunek ugrupowania, do którego przynależą. Od wyborców zależy sukces zawodowy polityków, tak jak od klientów linii lotniczych uzależniona jest praca stewardesy. „Ponadto, uzyskiwane rezultaty, w postaci reakcji elektoratu na poszczególne rodzaje informacji, podlegają stałej kontroli za pośrednictwem badań opinii publicznej" (Krawczyk-Antońska 2013: 63). „[...] politycy, współtworząc dyskurs polityczny: pragną stworzyć pozytywny wizerunek swojej osoby, wzbudzić przychylność audytorium dla siebie i prezentowanych przez siebie opinii, tak by przełożyło się to na korzystny wynik wyborczy, a jednocześnie osłabić pozycję przeciwników politycznych” (Miłkowska-Samul 2013: 173).

W kontekście analizy nad zarządzaniem emocjami przez marszałków, ważne jest zwrócenie uwagi na zarządzanie cudzymi emocjami. Zdolność zarządzania emocjami innych wydaje się odgrywać znaczącą rolę w jakości naszych relacji społecznych (Cheung, Gardner: 60). Osoby prowadzące obrady mają wachlarz możliwości wpływania na emocje na sali sejmowej. Celowe wpływanie na sposób, w jaki czują się inni, jest wszechobecne w życiu społecznym. Dawanie rad zmartwionemu przyjacielowi, krytykowanie kolegi, ignorowanie, aby sprawić, żeby ktoś poczuł się winny, lub żartowanie, aby ktoś poczuł się lepiej, to tylko kilka przykładów codziennych strategii wpływania na innych (Martinez-Inigo, Poerio, Totterdell 2013: 248). Tak jak w życiu codziennym każdy stosuje określone taktyki i sposoby wpływa- 
nia na cudze emocje, tak marszałkowie Sejmu często korzystają z tych nieformalnych, jednak mających silne oddziaływanie, technik, dzięki którym możliwa jest merytoryczna debata. Regulację emocji definiujemy jako proces inicjowania, utrzymywania lub zmiany występowania, intensywności lub czasu trwania wewnętrznych stanów uczuciowych i związanych z nimi emocjonalnych procesów fizjologicznych (Eisenberg, Fabes, Guthrie, Reiser 2000: 137). Wzbudzanie określonych emocji u posłów może powodować u nich występowanie określonych reakcji, które mogą potęgować np. poczucie wstydu (Sheff 2000). Zachowanie związane $\mathrm{z}$ emocjami jest definiowane jako proces inicjowania, utrzymywania, hamowania, modulowania lub zmiany występowania formy i czasu trwania zachowania powodowanego emocjami, włączając obserwowalne reakcje twarzy, gesty i inne zachowania, które wynikają lub są związane z psychologicznymi lub wewnętrznymi stanami psychologicznymi lub fizycznymi (Eisenberg, Fabes, Guthrie, Reiser 2000: 138).

Nawet chwilowa zmiana emocji u osoby przemawiającej z mównicy może spowodować, że przyjmie ona zupełnie inną formę i styl wypowiedzi. Po opanowaniu emocji nie będzie ona już miała możliwości do przedstawienia swojego stanowiska - harmonogram obrad i kolejność wypowiedzi posłów przebiega zgodnie z przyjętym planem.

\section{Analiza}

Marszałek pełni najważniejszą funkcję w Sejmie, od niego zależy przebieg obrad, „sprawuje pieczę nad spokojem i porządkiem na całym obszarze należącym do Sejmu oraz wydaje stosowne zarządzenia porządkowe, w tym o użyciu w razie konieczności Straży Marszałkowskiej” (Regulamin Sejmu Rzeczypospolitej Polskiej, art. 10). Oznacza to, że musi być również „strażnikiem 
emocji”. Wchodzi w interakcje, które można rozumieć jako to „Co w niepowtarzalny sposób zdarza się w sytuacjach społecznych, tj. w środowiskach, w których jednostki (dwie lub więcej) wzajemnie reagują na swoją obecność" (Goffman 2006: 293), ze wszystkimi posłami, którzy są obecni na sali sejmowej podczas prowadzenia obrad.

Najbardziej charakterystyczne style w prowadzeniu obrad, zarządzaniu emocjami sali sejmowej, prezentują: Cezary Grabarczyk, Stefan Niesiołowski, Ewa Kopacz oraz po objęciu przez Ewę Kopacz urzędu Prezesa Rady Ministrów (09.2014) - Radosław Sikorski.

Cezary Grabarczyk biurokratyzuje debatę, stara się nie poddawać emocjom. Jest opanowany, w trudnych chwilach opiera się na regulaminie, nie przywiązując większej wagi do komentarzy innych posłów (http://www.youtube.com/watch?v=B7J_gJyrtvk [dostęp 11.2014]; http://www.youtube.com/watch?v=k3dwsGJQEqg [dostęp 01.2015]). Reprezentuje twardy styl, z odwołaniem do procedur dyscyplinarnych. Procedura jest dla niego narzędziem objaśniającym i uzasadniającym decyzje. W momencie gdy Marszałek nie może zapanować nad salą sejmową, zarządza przerwę. Jeśli po zwróceniu uwagi nie ma reakcji ze strony sali sejmowej, Marszałek podnosi głos i stanowczo podkreśla swoją wolę - decyzję (http://www.youtube.com/watch?v=0T36hT3OWFg [dostęp 01.2015]).

Podsumowując, Cezary Grabarczyk stara się zapanować nad posłami w sposób sformalizowany, nie ulega emocjom, nie wchodzi w dyskusję z posłami. W trudnych chwilach opiera się na przepisach i regulaminie.

Stefan Niesiołowski jest marszałkiem, który dyscyplinuje posłów dostępnymi mu środkami (regulamin oraz techniczne utrudnianie zabrania głosu - wyłączając np. mikrofon). Marszałek odmawia możliwości wystąpienia posłom, w przypadku niepodporządkowania się podnosi głos, okazuje swoją władzę. 
Panie, Pan może wzywać do porządku jak będzie Marszałkiem, a na razie Pan nie jest...

Marszałek Niesiołowski podpiera się regulaminem, kiedy jeden z posłów nie ustępuje i nalega na zabranie głosu, wyłącza mikrofon i zachowuje bierną postawę (http://www.youtube.com/ watch?v=HkxsuJhFAPM [dostęp 11.2014]). Wzbudza on u posłów wstyd i zakłopotanie.

Prowadzenie debaty przez Ewę Kopacz charakteryzuje zdecydowana postawa wobec niezdyscyplinowanych posłów. Do uczestników debaty odnosi się jak do dzieci.

Proszę Pana przewodniczącego o chwilę spokoju, bo prawa strona, po wysłuchaniu swojego wystąpienia stwierdziła, że pańskie wystąpienie będzie mało interesujące, więc zamierza opuścić salę... kto, kto ma ochotę, to proszę opuścić salę, ale nie przeszkadzać... Proszę nie pokrzykiwać Panie Pośle, kto nie ma ochoty słuchać, proszę wyjść, ale nie odwracać się tyłem do mówiącego, bo to jest niegrzeczne [...]. Czy chce Pan, czy Pan chce polemizować w tej chwili, czy Pan przeszkadza, czy Pan nie przeszkadza w prowadzeniu obrad.

Radosław Sikorski w dyscyplinowaniu posłów, podobnie jak poprzednicy, posługuje się techniką (wyłączanie mikrofonu) oraz humorem (https://www.youtube.com/watch?v=g-Qsd-Smj-s [dostęp 02.2015]).

Rozumiem, że w trybie sprostowania, chce pan przeprosić za swoje zachowanie. Panie pośle ja znałem lady Margaret Thatcher, pan nie jest politykiem jej wymiaru...

$\mathrm{Na}$ oskarżenie poseł Pawłowicz, że Marszałek sprawuje swoją funkcję w sposób niewłaściwy, Sikorski reaguje spokojnie i odpowiada $\mathrm{z}$ humorem (https://www.youtube.com/watch?v=gktmLLVI2Xg [dostęp 02.2015]).

Czy Pani poseł zaprzecza, jakoby konsumowała na Sali? 
W przypadku gdy posłowie nie przestrzegają zasad prowadzenia obrad, Marszałek przywołuje ich do siebie. Wydaje się, że Radosław Sikorski zachowuje najwięcej spokoju spośród marszałków Sejmu, których obrady zostały poddane analizie.

Jeden z marszałków - Jerzy Wenderlich, bezpośrednio wskazuje na rolę urzędu w zarządzaniu emocjami.

Dziękuję, panie pośle. Marszałek prowadzący oczywiście będzie oceniał poziom emocji, który jest na tej sali, bo mam do tego prawo. Uważam, że nie powinniśmy procedować drastycznie. Kontynuujemy tę dyskusję. W imieniu klubu Prawa i Sprawiedliwości głos zabierze pan poseł Bartosz Kownacki, którego proszę o zabranie głosu.

Rolą Marszałka Sejmu - poza oczywistym faktem zarządzania przebiegiem debaty - jest „radzenie” sobie z emocjami, które pojawiają się na sali sejmowej. Najczęściej emocje pojawiają się w debatach dotyczących ważnych, kontrowersyjnych spraw.

Po przeprowadzonej analizie 20 obrad, w których była widoczna aktywna rola Marszałka Sejmu, można wyróżnić kilka stylów prowadzenia posiedzeń sejmowych: biurokratyczny, który opiera się na twardych przepisach i odwołaniach do regulaminu (Cezary Grabarczyk), emocjonalny (Ewa Kopacz), w którym Marszałek używa języka nacechowanego emocjami lub drwi z posłów, aby przywołać ich do porządku:

Proszę nie pokrzykiwać Panie Pośle, kto nie ma ochoty słuchać, proszę wyjść, ale nie odwracać się tyłem do mówiącego, bo to jest niegrzeczne; Pani Poseł należą się przeprosiny, od tych, którzy zachowywali się niegrzecznie na tej Sali.

Styl emocjonalny opiera się na odwołaniu się do podstawowych uczuć u posłów: wstydu (zwracanie się do posłów jak do dzieci lub wmawianie braku rozumności), zażenowania (próba ośmieszenia posła, który nie podporządkowuje się regulaminowi), dumy (próba urażenia dumy posła). Techniki wpływania na 
emocje (np. ośmieszenie, krytykowanie itp.) osób znajdujących się na sali sejmowej są istotnym (nieformalnym) narzędziem, dzięki któremu Marszałek może zarządzać przebiegiem obrad.

Ostatni styl prowadzenia obrad jest połączeniem formalnego i emocjonalnego (Stefan Niesiołowski), opiera się na wykorzystaniu regulaminu oraz ostrego języka - pokrzykiwanie, brak próby nawiązania dialogu z innymi posłami (niesłuchanie argumentów), obraza posłów:

[...] bo wyłączę Panu mikrofon za niebywałe chamstwo; to co Pan robi jest chuligaństwem politycznym [...] może się Pan położyć jak poseł Janowski i nie chodzić do ubikacji, to już Pana sprawa jest [...].

\section{Wnioski}

Z przeprowadzonych analiz nasuwa się wniosek, że Marszałek Sejmu, wykorzystując wszystkie dostępne mu środki formalne (np. regulamin, Straż Marszałkowską itp.) oraz nieformalne (ironia), dba o prawidłowy przebieg obrad. Wydaje się, że gdyby nie jego praca, posłowie nie byliby w stanie dojść do porozumienia lub nawet wypowiedzieć się z sejmowej mównicy. Zdecydowana postawa Marszałka, charakteryzująca się unikaniem wchodzenia w polemikę z innymi posłami oraz używanie jednoznacznych uwag, które mają przywołać niezdyscyplinowanych uczestników obrad do porządku, powodują, że posiedzenia sejmowe mogą odbywać się w sposób efektywny (http://www.youtube.com/ watch?v=u6XmiFkWazI [dostęp 01.2015]):

[...] to co Pan robi, jest bezczelnym przerywaniem i zakłócaniem obrad, proszę o opuszczenie trybuny, nie udzielitem, zgodnie z regulaminem, głosu. To ja decyduję o tym, a nie Pan.

Przywoływanie posłów do porządku, formalna władza Marszałka - groźba użycia Straży Marszałkowskiej - uspokajają posłów. 
W ostateczności Marszałek może przerwać obrady, aby emocje na sali uspokoiły się.

W kontekście pracy nad emocjami i pracy z emocjami rola Marszałka jest znacząca. Niezdyscyplinowani posłowie, poza formalnymi możliwościami przywołania ich do porządku, są zawstydzani. Wstyd jako jedna $\mathrm{z}$ ważniejszych emocji regulujących zachowania w życiu codziennym (Shott 1979; Scheff, Retzinger 2000 i in.) silnie wpływa na zachowanie aktorów społecznych. Przesunięcie granicy tego, co rozumiane jest jako wstyd (Górska 2009), powoduje, że to właśnie osoba prowadząca posiedzenie sejmowe wskazuje, że zachowanie poszczególnych osób jest nieodpowiednie. W tym przypadku to Marszałek wskazuje, że normy zostały złamane i w ten sposób zawstydza posłów. Możliwość wzbudzenia zażenowania (Shott 1979) u osoby wypowiadającej się z mównicy, zdefiniowanie sytuacji przez Marszałka, że poseł zachowuje się niestosownie, podanie do wiadomości publiczności, że występ przebiega nieudolnie i tak ma być odbierany, to jedno z wielu narzędzi, którymi może dysponować najważniejsza osoba w Sejmie. Możliwość narzucenia tego, w jaki sposób mają być interpretowane zachowania posłów przez publiczność (zarówno znajdującą się na sali sejmowej podczas posiedzenia, jak i elektorat, który ma dostęp do tego, co dzieje się w trakcie debaty za pośrednictwem telewizji lub Internetu), sprawia, że posiadane nieformalne możliwości wpływu mogą w dużym stopniu nadać kierunek toczonym debatom. Ośmieszony poseł być może nie będzie w stanie dokończyć swojej wypowiedzi, wstyd, który się u niego pojawi, może również doprowadzić do wpadnięcia w pułapkę emocji (Scheff, Retzinger 2000) i sprawi, że osoba wypowiadająca się z mównicy będzie chciała jak najszybciej dokończyć swoją wypowiedź i „ukryć” się w ławie poselskiej.

Nierzadko posłowie, wobec których są kierowane negatywne emocje, bronią się, co prowadzi do ataków słownych na Marszałka. Ludzie wpływający na uczucia innych również mogą 
doświadczać zmian tych emocji w sobie (Niven, Totterdell, Holman, Headley 2012: 247), jednak władza formalna, którą posiadają, oraz praca nad emocjami innych na poziomie interakcji, w oparciu o zasoby strukturalne, w ostateczności prowadzi to zdyscyplinowania posłów.

Marszałek jest - używając terminologii Goffmanowskiej - reżyserem. Przywołuje on do porządku członków zespołu; w tym przypadku przez zespół należy rozumieć grupę posłów obecnych na posiedzeniu Sejmu. Ponadto na reżyserze spoczywa obowiązek „rozdania ról i dobrania dla wykonawców przedstawienia najlepszych fasad” (Goffman 2008: 128). Marszałek może również nakładać ramy interpretacyjne posiedzenia sejmowego wobec szerszej widowni - wyborców, którzy nie biorą czynnego udziału w przedstawieniu.

Wypowiadając z mównicy sejmowej określone poglądy, poseł stara się wywołać określone wrażenie, polega to na zastosowaniu pewnych wzorców - odnoszących się do sposobu, w jaki wykonawca traktuje widownię. Goffman proponuje nazwać te wzorce zasadami dobrego wychowania (Goffman 2008: 136), wzorce dotyczące sposobu, w jaki wykonawca zachowuje się w wizualnej czy głosowej obecności publiczności, nazywa dobrymi obyczajami (ibidem). Do roli Marszałka będzie również należała kontrola, dbanie o przestrzeganie zasad dobrego wychowania i dobrych obyczajów.

Poseł musi przyjąć sprecyzowany sposób działania, który jest pożądany przez obserwatorów (wyborców, kolegów partyjnych), żeby stał się wiarygodny podczas odgrywania roli. „Kiedy jednostka gra jakąśs rolę, oczekuje od obserwatorów, że wrażenie, jakie pragnie wywołać, odbiorą zgodnie z jej zamysłem" (Goffman 2008: 47). Jednak działania Marszałka mogą przedefiniować cały występ - ośmieszanie posłów lub formalne zakazy/nakazy potrafią zaburzyć całą grę. „Wychodząc z założenia, że jednostka, wkraczając w krąg obecności innych, narzuca im swoją definicję 
sytuacji, musimy również przyjąć, że w toku interakcji może się zdarzyć coś takiego, co tej definicji zaprzeczy, zdyskredytuje ją lub w jakiś sposób poda w wątpliwość. Kiedy dochodzi do tego rodzaju wstrząsów, interakcja ulega zatrzymaniu na skutek konfuzji i zakłopotania. Część założeń, na podstawie których przewidywano reakcje uczestników interakcji, okazuje się nie do utrzymania, oni sami zaś odkrywają, że są uwikłani w interakcję, w której sytuacja była źle zdefiniowana, a teraz w ogóle zdefiniowana nie jest" (Goffman 2008: 42). Możliwość powiedzenia ostatniego słowa przez Marszałka może spowodować zaburzenie występu, zakłopotanie posła, który naraził się Marszałkowi Sejmu, co zostanie szybko dostrzeżone przez widownię. „Na wyrazistość jednostki [...] składają się dwa zasadniczo odmienne rodzaje symbolicznej działalności: wrażenia, które ona przekazuje (gives) i które wywołuje (give off)" (Goffman 2008: 33). Wrażenia wywoływane opierają się na komunikatach bardziej teatralnych i kontekstowych. Sama pozycja Marszałka w sali sejmowej - w centrum, na podwyższeniu, sprawia, że jest on odbierany jako najważniejsza osoba w Sejmie, co również wynika z formalnych zapisów w Konstytucji, że jest on najważniejszą osobą w Państwie. Dlatego też konieczność zarządzania przez niego emocjami innych jest niezwykle trudna do zakwestionowania. 


\section{Aneks}

\section{Zadania Marszałka Sejmu (Regulamin Sejmu Rzeczypospolitej Polskiej)}

\section{Art. 10}

1. Marszałek Sejmu:

1) Stoi na straży praw i godności Sejmu.

2) Reprezentuje Sejm.

3) Zwołuje posiedzenia Sejmu.

4) Przewodniczy obradom Sejmu.

5) Czuwa nad tokiem i terminowością prac Sejmu i jego organów.

6) Kieruje pracami Prezydium Sejmu i przewodniczy jego obradom.

7) Zwołuje Konwent Seniorów i przewodniczy jego obradom.

8) Nadaje bieg inicjatywom ustawodawczym i uchwałodawczym oraz wnioskom organów państwa skierowanym do Sejmu, po zasięgnięciu opinii Prezydium Sejmu.

8a) Nadaje bieg dokumentom przedkładanym w sprawach związanych z członkostwem Rzeczypospolitej Polskiej w Unii Europejskiej.

9) Prowadzi sprawy z zakresu stosunków z Senatem.

10) Prowadzi sprawy z zakresu stosunków Sejmu z parlamentami innych krajów.

10a) Prowadzi sprawy z zakresu stosunków Sejmu z instytucjami oraz innymi organami Unii Europejskiej.

11) Przedstawia okresowe oceny wykonania przez organy administracji państwowej obowiązków wobec Sejmu i jego organów oraz posłów; wnioski w tym zakresie przekazuje Prezesowi Rady Ministrów, prezydiom komisji sejmowych oraz posłom. 
12) Udziela posłom niezbędnej pomocy w ich pracy, w tym czuwa nad wykonaniem wobec posłów przez organy administracji rządowej i samorządu terytorialnego oraz inne jednostki organizacyjne obowiązków określonych w ustawie o wykonywaniu mandatu posła i senatora.

13) Sprawuje pieczę nad spokojem i porządkiem na całym obszarze należącym do Sejmu oraz wydaje stosowne zarządzenia porządkowe, w tym o użyciu w razie konieczności Straży Marszałkowskiej.

14) Nadaje, w drodze zarządzenia, statut Kancelarii Sejmu.

15) Ustala projekt budżetu Kancelarii Sejmu, po zasięgnięciu opinii Komisji Regulaminowej i Spraw Poselskich i Prezydium Sejmu, oraz nadzoruje jego wykonanie.

16) Powołuje i odwołuje Szefa Kancelarii Sejmu, po zasięgnięciu opinii Komisji Regulaminowej i Spraw Poselskich.

17) Powołuje i odwołuje zastępców Szefa Kancelarii Sejmu, po zasięgnięciu opinii Szefa Kancelarii Sejmu.

18) Podejmuje inne czynności wynikające z Regulaminu Sejmu.

2. Marszałek Sejmu wykonuje także inne zadania przewidziane w Konstytucji i w ustawach.

3. Marszałka Sejmu w zakresie przez niego określonym zastępują wicemarszałkowie Sejmu. 


\title{
MANAGING EMOTIONS IN THE POLISH PARLIAMENT. THE MARSHAL'S ROLE
}

\begin{abstract}
This paper analyzes actions taken by the Marshals of the Polish Parliament to control the emotions that appear in the parliamentary hall during the meeting and debates. The author has focused on interactional techniques (both formal and informal) used by the marshals to conduct the parliamentary debate in the most effective way. This article aims to analyze techniques, which are at Marshall's disposal in order to prevent Parliamentary debates from getting disturbed by emotions.
\end{abstract}

Key words: sociology of emotions, politics, emotion management, shame, symbolic interactionism, Erving Goffman, Thomas Scheff, Arlie Russel Hochschild

\section{Bibliografia}

Charmaz, Kathy (2009), Teoria ugruntowana, PWN, Warszawa

Cheung, Elaine O., Wendi L. Gardner (2015), The way I make you feel: Social exclusion enhances the ability to manage others' emotions, „Journal of Experimental Social Psychology", 60, 59-75, http://dx.doi. org/10.1016/j.jesp.2015.05.003 [dostęp 06.2015]

Eisenberg, Nancy, Richard A. Fabes, Ivanna K. Guthrie, Mark Reiser (2000), Dispositional Emotionality and Regulation: Their Role in Predicting Quality of Social Functioning, „Journal of Personality and Social Psychology", vol. 78 , no. $1,136-157$

Elias, Norbert (1980), Przemiany obyczajów w cywilizacji Zachodu, Państwowy Instytut Wydawniczy, Warszawa
Fras, Janina (2005), Komunikacja polityczna. Wybrane zagadnienia gatunków i języka wypowiedzi, Wrocław

Goffman, Erving (2006), Porządek interakcyjny, [w:] Współczesne teorie socjologiczne, wybór i opracowanie Aleksandra Jasieńska-Kania, Lech M. Nijakowski, Jerzy Szacki, Marek Ziółkowski, Scholar, Warszawa

Goffman, Erving (2008), Człowiek w teatrze życia codziennego, Aletheia, Warszawa

Górska, Joanna (2009), Wstyd w ponowoczesności, [w:] Emocje a kultura $i$ życie codzienne, red. Piotr Binder, Hanna Palska, Wojciech Pawlik, Wyd. IFiS PAN 2009

Hochschild, Arlie Russell (2009), Zarzadzanie emocjami. Komercjalizacja ludzkich uczuć, PWN, Warszawa 
Konecki, Krzysztof T. (2014), Socjologia emocji według Thomasa Scheffa, [w:] Emocje w życiu codziennym. Analiza kulturowych, społecznych i organizacyjnych uwarunkowań ujawniania $i$ kierowania emocjami, red. Krzysztof T. Konecki, Beata Pawłowska, Wydawnictwo Uniwersytetu Łódzkiego, Łódź, s. 11-38

Krawczyk-Antońska, Żaneta (2013), Pobudzić a zostać pobudzonym. Emocje w polityce, Oficyna Wydawnicza, Katowice

Martinez-Inigo, Davis, Lara Giulia Poerio, Peter Totterdell (2013), The Association between Controlled Interpersonal Affect Regulation and Resource Depletion, „Applied Psychology: Health and Well-bing", 5 (2), s. 248-269

Miłkowska-Samul, Kamila (2013), Emocje a skandal polityczny. O sposobach wykorzystywania emocji w dyskursie politycznym, „Przegląd Socjologii Jakościowej", t. 9, nr 2, s. 164-183, www.przegladsocjologii jakosiowej. org [dostęp 15.09.2014]

Niven, Karen, Peter Totterdell, David Holman, Tara Headley (2012), Does Regulating Others' Feelings Influence People's Own Affective Well-Being?, „The Journal of Social Psychology”, 152(2), s. $246-260$

Regulamin Sejmu Rzeczypospolitej Polskiej z dnia 30 lipca 1992 r., http:// www.sejm.gov.pl/prawo/regulamin/ kon7.htm

Scheff, Thomas J., Suzanne M. Retzinger (2000), Shame As The Master Emotion of Everyday Life, „Journal of Mundane Behavior", vol. 1, no. 3 (October), http://www.mundanebehavior.org/ issues/v1n3/scheff-retzinger.htm [dostęp 15.04.2013]

Shott, Susan (1979), Emotion and social life: A symbolic interactionist analysis, "The American Journal of Sociology", vol. 84, no. 6 (May), s. 1317-1334

Turner, Jonathan H. (2008), Struktura teorii socjologicznej, PWN, Warszawa 